\title{
Improvement of the Technology Packaging for the Transportation of Mangosteen
}

\author{
Perbaikan Teknologi Pengemasan Pada Transportasi Buah Manggis \\ Niluh Yulianti ${ }^{1}$, Sutrisno ${ }^{2}$ dan Emmy Darmawati ${ }^{3}$
}

\begin{abstract}
The research aimed to design a package made of corrugated board for mangosteen packaging; test the compression strength of the packaging; analyze the effect of packaging capacity and fruit packing pattern in the container on some quality parameters after transport, and analyze the economy of the packaging used.The research was conducted in three stages, namely: the measurement of physical and mechanical properties of fruit (Stage I); the packaging design i.e. determining the packaging dimension (Stage II); and packaging design testing (Stage III). Compression and vibration testing were conducted. For the vibration testing, transport simulations were conducted using the vibration simulator of $3.50 \mathrm{~Hz}$ and amplitude of 4.61 $\mathrm{cm}$ for 3 hours. The packaging was designed with a capacity of $8 \mathrm{~kg}$ and $15 \mathrm{~kg}$ using two packing pattern, namely the fcc and Jumble. Based on the physical and mechanical properties, optimal packing pattern of $8 \mathrm{~kg}$ container was 8,4 , and 4 pieces of fruit for the long $x, y$, and $z$ direction, respectively, with the density of $62 \%$. Therefore, gave packaging dimension of $39.4 \times 21 \times 21 \mathrm{~cm}$. For the $15 \mathrm{~kg}$ container, the optimal packing pattern was 8,6 and 5 pieces of fruit for the $x, y$, and $z$ direction, respectively, with the packing density of $65.6 \%$. Thus, gave dimension of $39.4 \times 30 \times 25 \mathrm{~cm}$. Based on overall test results, it can be stated that the design packaging capacity of $8 \mathrm{~kg}$ with dimension of $39.4 \mathrm{~cm} \times 21 \mathrm{~cm} \times 21 \mathrm{~cm}$ and the fcc packing pattern gave the optimal setting for mangosteen transportation.
\end{abstract}

Keywords: packaging design, fcc, jumble, transportation, mangosteen

Diterima: 18 September 2009; Disetujui: 25 Februari 2010

\section{Introduction}

Mangosteen is Indonesia predominant export commodity which is potential to be developed with transportation as its critical part in the post-harvest activities. Transportation becomes very important because in general mangosteen production is concentrated onlyin someareas, while the consumers spread across the country even abroad. During transportation, mangosteen experiences various risks of physical damage in the form of friction and collisions that cause mechanical damage (Peleg, 1985). Product that has undergone mechanical injury will be more vulnerable to physiological and biological damages (Satuhu, 2004).

Facts in the field show that generally mangosteen is packed in plastic baskets of $45 \mathrm{~cm} \times 35 \mathrm{~cm} \times 15 \mathrm{~cm}$ with a capacity of $8 \mathrm{~kg}$ to $10 \mathrm{~kg}$ in bulk. This kind of packaging and handling causes post-harvest loss due to transport by $20 \%$. This number can be significantly reduced by designing and applying a good and effective transport packaging. The design of a good transport packaging requires suitability of packing material with the characteristics of the packaged products. Corrugated cardboard is a suitable packaging material for fruit products such as mangosteen because it has advantages such as vibration damping, pressure resistance, smooth surface and the type of packaging material received in international markets (Syerief, 1989).

In general, this research aims to design a package made of corrugated board for mangosteen packaging; test the compression strength of the packaging; and analyze the influence of packaging capacity and the fruit packing system inside the container on some quality parameters after transport. The study specifically aims to determine the effective fruit packing system inside packaging (number of fruits in the line/column); determine the dimensions of packaging (inner packaging, packaging designs and outer packaging); and perform cost analysis of the designed packaging.

\footnotetext{
Alumni Program Magister Teknik Mesin Petanian dan Pangan SPs IPB, Email: yuli_ibonk@yahoo.co.id

Staf Pengajar Departemen Teknik Pertanian-Fakultas Teknologi Pertanian- Institut Pertanian Bogor

Staf Pengajar Departemen Teknik Pertanian, Fakultas Teknologi Pertanian Bogor. Email: emi_handono@yahoo.com
} 


\section{Materials and Methodes}

\section{Materials and Equipments}

The materials used are first quality, index 2 mangosteen with a diameter of $6.0 \mathrm{~cm}-6.5 \mathrm{~cm}$ and the designed packaging (BC flute corrugated cardboard). The instruments used are: Instron universal testing machine, vibrating table, Mettler PM - 4800 electronic balance, and carpentry tools.

\section{Research Procedures}

The study consisted of 3 stages:

\section{Stage I}

In stage I, measurement of physical properties and mechanical properties of fruit was conducted. The physical properties such as fruit dimensions (major and minor diameter of the fruit), the average fruit weight, fruit height and stem height were measured. Measurement of mechanical properties of fruit was done by giving vertical load on individual fruit sample.

\section{Stage II}

In stage II, designing the packaging was performed. Dimension of the inner, design and outer packaging was calculated by using the following equation:

a. Counting the number of fruits $(\mathrm{N})$ in the packaging

$N=$ Number of Fruits in $1 \mathrm{~kg}$ x packaging capacity $(\mathrm{kg})$

Counting the number of fruit in each row/ column in the packaging

$F v(n)=L x \frac{M}{d}$

Nonsymmetric row pattern $(N)=\frac{(K A K B K C)}{2}$

Symmetric row pattern $(N)=\frac{(K A K B K C+1)}{2}$

$\mathrm{KA}, \mathrm{KB}$ and $\mathrm{KC}$ are number of fruit on the length, width and height in packaging, respectively. L, M, d ?

b. Counting dimensions of inner packaging

Lenght of fcc $(A)=(1.41 K A+0.59) a$

Widht of $f c c(B)=(1.41 K B+0.59) b$

Height of $f c c(C)=(1.41 K C+0.59) b$

where $a$ and $b$ is the radius of major and minor fruit. c. Counting dimensions packaging design

$$
\begin{aligned}
& \text { Lenght }=\text { Lenght of } f c c(A)+8 \\
& \text { Widht }=\text { Widht of } f c c(B)+4 \\
& \text { Height }=\text { Height of } f c c(C)+4 \\
& \text { Flap }=(\text { Widht of } f c c(B)+8) / 2
\end{aligned}
$$

3. Stage III

In stage III, compression strength test and transport simulation of the designed packaging were performed. Compression strength test to the packaging was conducted in two forms i.e. direct compression strength test using a universal testing machine and calculated compression strength (Equation 5). Transport simulation was performed using vibration table of $3.50 \mathrm{~Hz}$ and amplitude of 4.61 for 3 hours. Out of town or long distance road transport with truck was applied in the simulation for the equality of vibrating table with the real transport situations (Construction Testing Institute, 1986).

$B=1.82 \times P m \times \sqrt{h} \times \sqrt{Z}$

where $\mathrm{Pm}, \mathrm{h}$ and $\mathrm{Z}$ are the strength angle of corrugated cardboard, the thickness of corrugated cardboard, and circumference, respectively.

Transport simulation was carried out to study the characteristics of the packaging design and fruit packing patterns inside containers to changes in product quality. The packaging was designed in RSC type with a capacity of $8 \mathrm{~kg}$ and $15 \mathrm{~kg}$ using two patterns of fruit packing systems, namely the fcc (face centered cubic) and jumble foam net. The design applied $C$ ircles for ventilation with a total of $3 \%$ of the total surface packaging. Experimental design used in the study was completely randomized design with 2 factors for the analysis of quality parameters after transport.

\section{Results and Discussion}

\section{Stage I Measurement of Physical and Mechanical Properties}

A high level of uniformity in the dimensions of mangosteen fruit was found. It is shown by the low standard deviation value of the measurement data which is between $1.41-2.7$. The Fcc pattern is a packing pattern focusing on the same amount of fruits in a packaging capacity, therefore the fruits must have dimensions that are not much different from each other. The number of fruits that can be packed for each treatment capacity is 64 fruits for packaging with a capacity of $8 \mathrm{~kg}$ with a net weight 
Table 1. Dimensions of the designed inner packaging

\begin{tabular}{llcc}
\hline \multirow{2}{*}{ Parameters } & \multicolumn{2}{c}{ Capasity } \\
\cline { 3 - 4 } Number of Fruits & & $8 \mathrm{~kg}$ & $15 \mathrm{~kg}$ \\
\hline The amount of fruit in a row (fruit) & Leght direction $(\mathrm{KA})$ & 64 & 120 \\
& Width direction $(\mathrm{KB})$ & 4 & 8 \\
& Heightdirection $(\mathrm{KC})$ & 4 & 5 \\
\hline Distance between the fruit $(\mathrm{mm})$ & Leght direction $(\Delta \mathrm{x})$ & 25.62 & 25.62 \\
& Width direction $(\Delta \mathrm{y})$ & 26 & 26 \\
& Height direction $(\Delta \mathrm{z})$ & 23.92 & 23.92 \\
\hline Dimensions of inner package $(\mathrm{cm})$ & Lenght $(\mathrm{A})$ & 37.1 & 37.1 \\
& Width $(\mathrm{B})$ & 19.5 & 28.3 \\
& Height $(\mathrm{C})$ & 19.7 & 23.8 \\
\hline Volume $\left(\mathrm{cm}^{3}\right)$ & Fruit in the package & 8181.2 & 15339.8 \\
& Package & 13126.8 & 23384.4 \\
\hline Packing density $(\%)$ & & 62 & 65,6 \\
\hline
\end{tabular}

Table 2. Dimension of each design packaging capacity

\begin{tabular}{ccccc}
\hline Packaging Capacity & Length $(\mathrm{cm})$ & Width $(\mathrm{cm})$ & Height $(\mathrm{cm})$ & Flap $(\mathrm{cm})$ \\
\hline $8 \mathrm{Kg}$ & 38.8 & 20.4 & 20.4 & 10.4 \\
$15 \mathrm{Kg}$ & 38.8 & 29.4 & 24.4 & 14.9 \\
\hline
\end{tabular}

Table 3. Dimensions outside of the package

\begin{tabular}{cccc}
\hline Packaging Capacity & Length $(\mathrm{cm})$ & Width $(\mathrm{cm})$ & Height $(\mathrm{cm})$ \\
\hline $8 \mathrm{Kg}$ & 39.4 & 21 & 21 \\
$15 \mathrm{Kg}$ & 39.4 & 30 & 25 \\
\hline
\end{tabular}

of $8 \mathrm{~kg} \pm 0.1 \mathrm{~kg}$ per packaging, and 120 fruits for packaging with a capacity of $15 \mathrm{~kg}$ with net weight of $15 \mathrm{~kg} \pm 0.3 \mathrm{~kg}$ per packaging.

Test of mechanical properties was performed to determine the maximum load that can be accepted by the fruit without causing damage to the fruit. From the results of the test, it was known that the average bioyield of mangosteen is $6.53 \mathrm{kgf}$ and deformation is $0.46 \mathrm{~cm}$.

\section{Stage II Determination of Packaging Dimensions}

1. Determination of inner packaging dimensions

Determination of inner packaging dimensions is based on the amount of fruits contained inside one packaging capacity, where the combination of the value of $K A, K B$ and $K C$ (Equation 2) is selected for a combination that produces the highest percentage of packaging density and one that has a length-width ratio of 2:1. According to Tugimin (1993), design of a good RSC packaging has limit values for KA and $\mathrm{KB}$ that is the ratio of its length and width should equal to $2: 1$, while the $\mathrm{KC}$ value is limited by the height of the fruit piles inside containers that does not exceed its bioyield.

2. Determination of design and outer packaging dimensions

Design dimension is calculated using Equation 4 and the results of are shown in Table 2. 
Table 4 The net weight and number of fruits per capacity

\begin{tabular}{cccccc}
\hline \multirow{2}{*}{ Capacity $(\mathrm{kg})$} & Dimensions $\left(\mathrm{cm}^{3}\right)$ & \multicolumn{2}{c}{ Number of fruits (fruit) } & \multicolumn{2}{c}{ Net Weight $(\mathrm{kg})$} \\
\cline { 3 - 6 } & & $F c c$ & jumble & Fcc & jumble \\
\hline 8 & $39.4 \times 21 \times 21$ & 64 & 44 & $8 \pm 0.1$ & $5.38-5.48$ \\
15 & $39.4 \times 30 \times 25$ & 120 & 80 & $15 \pm 0.3$ & $9.94-10.44$ \\
\hline
\end{tabular}

Dimensions of outer packaging is the sum of the design dimension and the thickness of flute type in which from the measurement, thickness of flute type $\mathrm{BC}$ is $6 \mathrm{~mm}$. Therefore, the outer dimensions of the packaging can be derived as shown in Table 3 .

\section{Stage III Compression Stength Test and Transport Simulation}

During transportation, cardboard boxes are stored in a carrier space (container) stacked with other containers, and this condition causes top to bottom compression. To prevent damages to the packaging and packaged products due to congestion, compression strength tests and calculations were conducted to determine the maximum pile load of the designed packaging. The results of the calculation for the theoretical compression strength for the 8 $\mathrm{kg}$ packaging was $201.01 \mathrm{kgf}$ and $15 \mathrm{~kg}$ packaging was $216.47 \mathrm{kgf}$, while direct compression strength test of $8 \mathrm{~kg}$ packaging capacity was $204 \mathrm{kgf}$ and $15 \mathrm{~kg}$ packaging capacity was $256 \mathrm{kgf}$. The results showed that mathematical equations can be used to estimate the direct compression strength with accuracy of $98.5 \%$.

The height of packaging pile depends on each packaging net weight and the safety factor used. For the same dimensions of packaging, but different fruit packing system, each packaging will have different net weight. The net weight of measurements and calculations for each packaging capacity and fruit packaging pattern are shown in Table 4.

The net weight and number of fruits per capacity in Table 4 show that the number of packed fruits with fcc pattern is 30\% more than that of Jumble patterns for the same package dimensions. The difference in number and weight is because on the fcc pattern

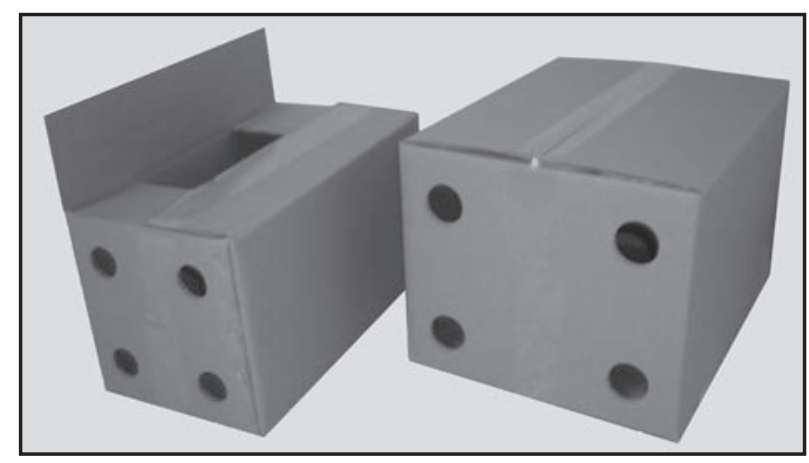

Figure 1 Packaging design results fruits are set and arranged with the same pattern hence the use of space becomes more effective. In addition, on Jumble pattern fruits are packaged with net foam before inserted into the cartons. Net foam addition is actually intended to protect the fruits from scratches and collisions, but with such condition less fruits are packed.

To obtain the equality of a long distance road transportation, then the transport simulations was carried out on a vibrating table with the average frequency of $3.50 \mathrm{~Hz}$, average amplitude of $4.61 \mathrm{~cm}$, and vibrated for 3 hours. Based on calculations, such condition is equal to a road journey as far $477.5 \mathrm{~km}$ with trucks on a frequency of $1.4 \mathrm{~Hz}$ and amplitude of $1.74 \mathrm{~cm}$ on a trip out of town. This condition may represent the distance between the centers of mangosteen production to the place where it will be exported. Sudibyo (1992) stated that during truck transportation, the products experience shocks especially in the vertical direction. Other shocks in the form of torsion and dings were ignored because they have a very small frequency. Based on these conditions, the use of vibrating table as a tool for transport simulations is appropriate because the resulting dominant turbulence of the vibration table is also in the vertical direction.

\section{Product Quality Changes after Transport}

1. Physical Damage

Mangosteen is subject to injury when these conditions are found: scar on the rind or dented fruit, broken calyx (petal), broken stems, and cracked skin. In this study, dented fruit and broken petals were found during the vibrating test.

Physical damage such as dented fruit is easily indicated by visual observation. The fruit skin is marked with severe bruises that give an unsmooth shape of surface skin. From observation, the level of total physical damage to the packaging with fcc fruit pattern was $(2.3 \%-75 \%)$ greater than that of the Jumble pattern $(2.3 \%-2.5 \%)$. The difference in physical damage because the number of fruits packed in the packaging with fcc pattern was more than that of the Jumble patterns. As a result, the load received by the fruits with the fcc pattern becomes larger. Another cause is because the fruits in the fcc pattern inside the corrugated cardboard carton are arranged without using net foam as in the Jumble patterns. This treatment has made pressure, friction and collisions among fruits in the fcc pattern and 
Table 5 Results of further tests in the interaction treatment to weight loss

\begin{tabular}{lcc}
\hline \multicolumn{1}{c}{ Treatment } & Average lost weight (\%) & Notation \\
\hline Capacity 8 Jumble $\left(\mathrm{K}_{8} \mathrm{P}_{\mathrm{j}}\right)$ & 1.20 & $\mathrm{a}$ \\
Capacity 8 Fcc $\left(\mathrm{K}_{8} \mathrm{P}_{\mathrm{f}}\right)$ & 1.09 & $\mathrm{~b}$ \\
Capacity 15 Jumble $\left(\mathrm{K}_{15} \mathrm{P}_{\mathrm{j}}\right)$ & 1.11 & $\mathrm{~b}$ \\
Capacity 15 Fcc $\left(\mathrm{K}_{15} \mathrm{P}_{\mathrm{f}}\right)$ & 1.05 & $\mathrm{~b}$ \\
\hline
\end{tabular}

caused direct contact on the fruit skin surface. Mangosteen skin/rind has a susceptible structure that is easily broken and not flexible, therefore physical damage in the form of dented fruit, although only a small curve, is clearly seen on fruits packed without using net foam.

The physical damage that occured in fruits arranged with fcc pattern was only in the form of dented rinds, while the physical damage to the fruit arranged in a Jumble pattern experienced broken calyx and dented rind. Condition of complete calyxes is one of the quality parameters of mangosteen fruit that taken into account in international market. Therefore, the fcc packing pattern can be applied to avoid broken calyxes on mangosteen transportation.

\section{Weight loss}

Based on observations made for 10 days in each packaging and fruit pattern treatment, it was found that weight loss in each treatment increasing (Figure 3). The lowest average value of weight loss (Table 5) was found in the fruits packed with a $15 \mathrm{~kg}$ packaging using fcc pattern (K15Pf), in the amount of $1.05 \%$, while the highest weight loss was found in fruits packed with a $8 \mathrm{~kg}$ packaging using the Jumble pattern (K8Pj), in the amount of $1.20 \%$.

The high value of weight loss in $\mathrm{K}_{8} \mathrm{P}_{\mathrm{j}}$ treatment describes the high extent of damage occurred in this treatment among other treatments. On the other hand, the lowest value of weight loss in $\mathrm{K}_{15} \mathrm{P}_{\mathrm{f}}$ treatment illustrates the low level of damage. The fruit damage in $\mathrm{K}_{8} \mathrm{P}_{\mathrm{j}}$ treatment was because the fruits were unclosedly packed; hence the intensity of friction and collisions between fruits is higher causing considerable damage. High levels of damage on the fruit skin surface caused the loss of wax, mangosteen natural protective layer. As a result, transpiration activity and water loss take place much faster causing more weight loss. Utama (2002) stated that water loss of product is potentially occurred through natural openings found on the outer tissue surfaces of fresh products that are influenced by internal factors such as injury to the surface of the product.

The analysis of variance showed that fruit packing patterns, packaging capacity and their interaction have significant effect on weight loss. Further test of interaction between treatments (Table 5) showed that $\mathrm{K}_{8} \mathrm{P}_{\mathrm{j}}$ treatment is significantly different with the three other treatments, while $\mathrm{K}_{8} \mathrm{P}_{\mathrm{f}}$, and $\mathrm{K}_{15} \mathrm{P}_{\mathrm{j}}$, and $\mathrm{K}_{15} \mathrm{P}_{\mathrm{f}}$ treatments gave insignificant influence among treatments.

\section{Economic Analysis}

Economic analysis was performed to determine the level of economic losses and benefits due to physical damage after transport simulation of the designed packaging. Some assumptions were used in the calculation: the designed packaging was made by the packaging manufacturer and the selling price of mangosteen was $\mathrm{Rp} 35,000.00 / \mathrm{kg}$, and that to avoid damage in the bottom packaging due to the above packaging weight load on it, the piles of packaging were set not exceeding the maximum stress load of each packaging capacity. The costs analysis of the use of designed packaging resulted that the maximum profit of $\mathrm{Rp} 74,462,643.00$ obtained in the use of the $8 \mathrm{~kg}$ packaging with fcc pattern. The profit is gained from the 284 packaging/

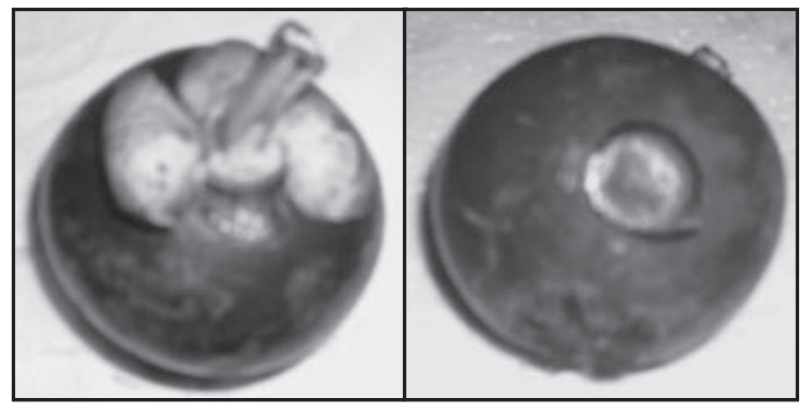

Figure 2 Physical damage on mangosteen (a) broken calyxes; (b) dented rind

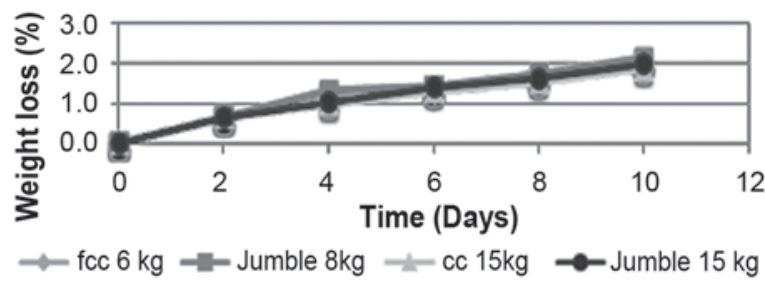

Figure 3 Graphs the changes decrease the weight 
truck with a capital cost of Rp 2,256,000.00 for the packaging manufacturing/truck.

Based on overall test results, it can be stated that the design of packaging capacity of $8 \mathrm{~kg}$ with dimension of $39.4 \mathrm{~cm} \times 21 \mathrm{~cm} \times 21 \mathrm{~cm}$ and fcc packing pattern gives the optimal setting for mangosteen transportation.

\section{Conclusion}

1. Based on the physical and mechanical properties, the optimal number of fruits on the $8 \mathrm{~kg}$ packaging is 8 fruits in the long direction, 4 fruits in width direction, and 4 fruits in the height direction with a packaging density of $62 \%$. The arrangement determines the packaging dimensions of $39.4 \mathrm{~cm}$ $\times 21 \mathrm{~cm} \times 21 \mathrm{~cm}$. For the $15 \mathrm{~kg}$ packaging, the optimal arrangement of the fruits on the lenght, width and height direction is 8 fruits, 6 fruits, and 5 fruits, respectively, with a packing density of $65.6 \%$. Dimensions of the $15 \mathrm{~kg}$ packaging was gained of $39.4 \mathrm{~cm} \times 30 \mathrm{~cm} \times 25 \mathrm{~cm}$.

2. The mathematical model can be used to predict compression strength value of the packaging without conducting the compression strength test directly , with the level of accuracy reached $98.5 \%$.

3. Based on overall test results, it can be stated that the packaging capacity of $8 \mathrm{~kg}$ size $39.4 \mathrm{~cm} \times 21$ $\mathrm{cm} \times 21 \mathrm{~cm}$ with fcc packing pattern gave the optimal settings for mangosteen transportation

\section{References}

Constuction Testing Institute. 1986. Results of Freight Truck Motion Transportation Equals to $30 \mathrm{~km}$ on Several Road Conditions. (in Bahasa Indonesia). Constuction Testing Institute. Jakarta.

Peleg, K. 1985. Produce Handling Packaging and Distribution. Avi Publishing Company, Inc. Westport, Connecticut

Satuhu, S. 1999. Handling of Fresh Mangosteen for Export (in Bahasa Indonesia). Penebar Swadaya. Jakarta

Sudibyo, M. 1991. Packaging and Transportation of Valensia Oranges. (in Bahasa Indonesia). Jurnal Hortikultura 1(2) : 49-53.

Sudibyo, M. 1992. Simulation Tools of Fresh Fruit Transportation using Cars and Trains. (in Bahasa Indonesia). Jurnal Hortikultura 2(1): 6-73.

Syarief, R., 1989. Food Packaging Technology. Books and Monograph. Laboratory of the InterUniversity Food and Nutrition. Institut Pertanian Bogor. Bogor.

Tugimin. 1986. Food Packaging with Cartons and the Techniques (in Bahasa Indonesia). Paper on Labor Supervision Training on Production Engineering in Food Industries Bogor Branch: various groups. 20 January-8 February

Utama, I Made. 2002. Horticulture Post Harvest Technology. (in Bahasa Indonesia). Assessment Center for Tropical Fruits Udayana University. Bali. 